\title{
Video Presentation about Menarche and the Impact on Student Knowledge Level of Elementary and Islamic Primary School
}

\author{
Asasih Villasari ${ }^{1}$, Sentot \\ Imam $^{2}$, Indasah $^{3}$ \\ ${ }^{1}$ Master Program of Public \\ Health, College of Health \\ Sciences Bhakti Husada \\ Madiun, Indonesia \\ ${ }^{2}$ IIK STRADA Indonesia \\ ${ }^{3}$ IIK STRADA Indonesia
}

Email:

as.villasari@gmail.com

Received : March $16^{\text {th }} 2021$

Accepted : April 16 2021

Published : May 20 2021

\begin{abstract}
Background: Some people feel it is taboo to talk about menstrual problems in their families, so that early adolescents do not have sufficient knowledge and attitudes about the physical and psychological changes related to menarche. Mental readiness is needed before menarche because feelings of anxiety and fear will arise, besides that, there is also a lack of knowledge about the selfcare needed during menstruation. Mental readiness is needed before menarche because feelings of anxiety and fear will arise, besides that there is also a lack of knowledge about the self-care needed during menstruation.

Method: The research design used the Quasy Expriement Study. The population was 152 students from Elementary School 02 and Islamic Primary School 01. With simple random sampling technique, it was obtained 112 respondents. The research instrument was a questionnaire.

Result: The results of the study were analyzed by using logistic regression. The results of the study showed that the significance of health education was $0.000<0.05$, so that there was an effect of health education using video on student anxiety levels with an influence coefficient value of 2.756. Meanwhile, for knowledge with a significant value of $0.028<0.05$, there is an effect of knowledge with the level of anxiety with an influence coefficient value of 1.354 .

Conclusion:The results of the analysis show that there is an effect of video exposure about menarche on the level of knowledge and anxiety levels in Elementary School 02 and Islamic Primary School 01 grade 4, grade 5 and grade 6 students in Gemarang, Madiun Regency.
\end{abstract}

Keywords: Video exposure, knowledge, anxiety, adolescents, menstruation

Copyright @ 2021 IIK STRADA Indonesia All right reserved.

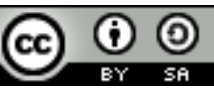

This is an open-acces article distributed under the terms of the Creative Commons Attribution-ShareAlike 4.0 International License. 


\section{INTRODUCTION}

Feelings of confusion, anxiety, and discomfort always envelop the feelings of a woman who is having her first menstrual period (menarche). The first menstruation or menarche is a natural thing that must be experienced by every normal woman who need not worry. However, this will get worse if the knowledge of adolescents about menstruation is very lacking and education from their parents is lacking. The existence of the wrong parents' assumption that this is a taboo subject to discuss and assuming the child will find out on his own, adds to the complexity of the problem. There is no need to be ashamed or anxious about menstruation. This actually shows that the body has grown up (Proverawati and Misaroh, 2012).

Based on the results of Riskesdas 2017, 5.2\% of children in Indonesia entered the age of menarche under the age of 12. In East Java, $74.8 \%$ of young women have normal nutritional status. As much as $25.3 \%$ of young women experience menarche at the age of 11-12 years (Kemenkes RI, 2017). Improving the standard of living has an impact on decreasing the age of menarche to a younger age (early menarche). This is associated with precocious puberty that occurs in children aged less than 12 years. Indonesia ranks 15 th out of 67 countries with a decline in the age of menarche reaching 0.145 years per decade. The shift of the age of menarche to a younger age will cause adolescent girls to experience the impact of emotional stress.

Anxiety is tension, discomfort and worry that arise because of the feeling that something unpleasant will happen, but the source is largely unknown (Maramis, 2014). Most children feel anxious when experiencing menarche because the most important event in girls' puberty is menstruation or menstruation symptoms, which are biological signs of sexual maturity. The acceptance of this period of sexual maturity with a sense of calm and pride, because they feel biologically mature. However, the younger the girl is and the more unprepared to accept the incident, it will cause disturbance or as a shock reaction in the child's assumptions and fantasies, on the other hand, because the child has never been exposed to health education about menstruation (Kartono, 2016).

Health education is the most important thing for someone to add insight, Health education as an essential component in nursing care which is directed at activities to improve, maintain, and honor health status, prevent disease and help individuals to overcome the effects of disease (Fitriani 2014). With a lot of someone's insight, someone will be more ready to face something without feeling anxious.

Solutions to reduce anxiety experienced by school age children. Providing health education using the video playback method is a highly recommended solution to overcome this problem. Health education is an activity or effort to convey health messages to groups or individuals. Health education obtained by respondents has an impact on increasing the respondent's knowledge. Young girls need to have knowledge about menarche from an early age, because this knowledge will later affect women's readiness to face menarche. Based on the research of Henny (2012) regarding the effect of health education on increasing the level of knowledge about menarche, it is revealed that there is a significant effect between health education on increasing the level of knowledge about menarch so, By increasing the knowledge of young women, it is hoped that later on, it can reduce the anxiety of teenage girls in facing menarche. Therefore, the researcher wanted to know the effect of exposure to video about menarche and its impact on knowledge levels and anxiety levels in adolescents.

Based on the description above, the problem formulation in this research proposal is "How is the effect of video exposur about menarche and its impact on the level of knowledge and level of anxiety in Elementary School 02 and Islamic Primary School 01 students in grade 4, grade 5 and grade 6 in Gemarang, Madiun Regency? " 
Video Presentation about Menarche and the Impact on Student Knowledge.....

\section{MATERIALS AND METHODS}

\section{Population}

The research population is a generalization area consisting of: objects / subjects that have certain qualities and characteristics that are determined by the researcher to be studied and then draw conclusions (Sugiono, 2010). The population in this study were all students in grades 4 - 6 Elementary School 02 and Islamic Primary School 01 who will face menarche at Gemarang 02 Elementary School, Gemarang sub-district, totaling 152 students.

\section{Samples and sampling}

\section{a. Sample}

The sample is part of the population to be studied / part of the number of characteristics possessed by the population (Hidayat, 2012). The sample in this study were students in grades 4 to 6 who will face menarche at Elementary School 02 and Islamic Primary School Gemarang, Gemarang sub-district.

\section{b. Sampling}

Sampling is the process of selecting a portion of the population to represent the population (Nursalam, 2016). In this study using a sampling technique, namely total sampling. Sample selection by random sampling, namely the sampling technique of members of the population which is done randomly without paying attention to the strata in the population (Sugiyono, 2012)

The number of samples, namely:

n: Number of Samples

$$
\mathrm{n}=\frac{N}{1+\mathrm{N}(d)^{2}}
$$

$\mathrm{N}$ : Total population

d: 0.05

$$
\begin{aligned}
\mathrm{n}= & \frac{152}{1+152(0,05)^{2}}=24.4 \\
= & \frac{152}{1+0,38} \\
= & \frac{152}{1,38} \\
& =110.0 \\
& =110
\end{aligned}
$$

So the number of samples in this study is 110 , of all the samples obtained, some will be taken for the treatment group, namely $(\mathrm{t}-1)(\mathrm{r}-1)>110$

\section{A. Variable Identification}

$$
\begin{gathered}
(3-1)(r-1)>110 \\
2 r-2>110 \\
2 r>110+2 \\
r=112 / 2 \\
r=56
\end{gathered}
$$

Research variables are characteristics possessed by members of a group (situation objects) that are different from those of the group (Nursalam, 2016).

The kinds of variables in this study are divided into:

1. Independent Variable (Free)

Independent variable (Free) is a variable that affects / its value determines other variables. A stimulus activity manipulated by the researcher creates an impact on the dependent variable (Nursalam, 2016). In this study, the independent variables were the level of knowledge and video exposure. 
2. Dependent Variable (Bound)

Dependent variable (Bound) is a variable that is influenced by its value determined by other variables. The response variable will appear as a result of the manipulation of other variables (Nursalam, 2016). In this study the dependent variable is anxiety.

\section{B. Operational definition}

The operational definition is to define a variable operationally based on the observed characteristics, thus enabling the researcher to make careful observations or measurements of an object or phenomenon. Operational definition is determined based on the parameters used as the measurement in the study (Hidayat, 2012).

Table 1. Operational Definition of Anxiety Level Analyst Based on Knowledge Level and Video Exposure about Menarch in SD 02 and MI 01 Students in Gamarang, Madiun Regency

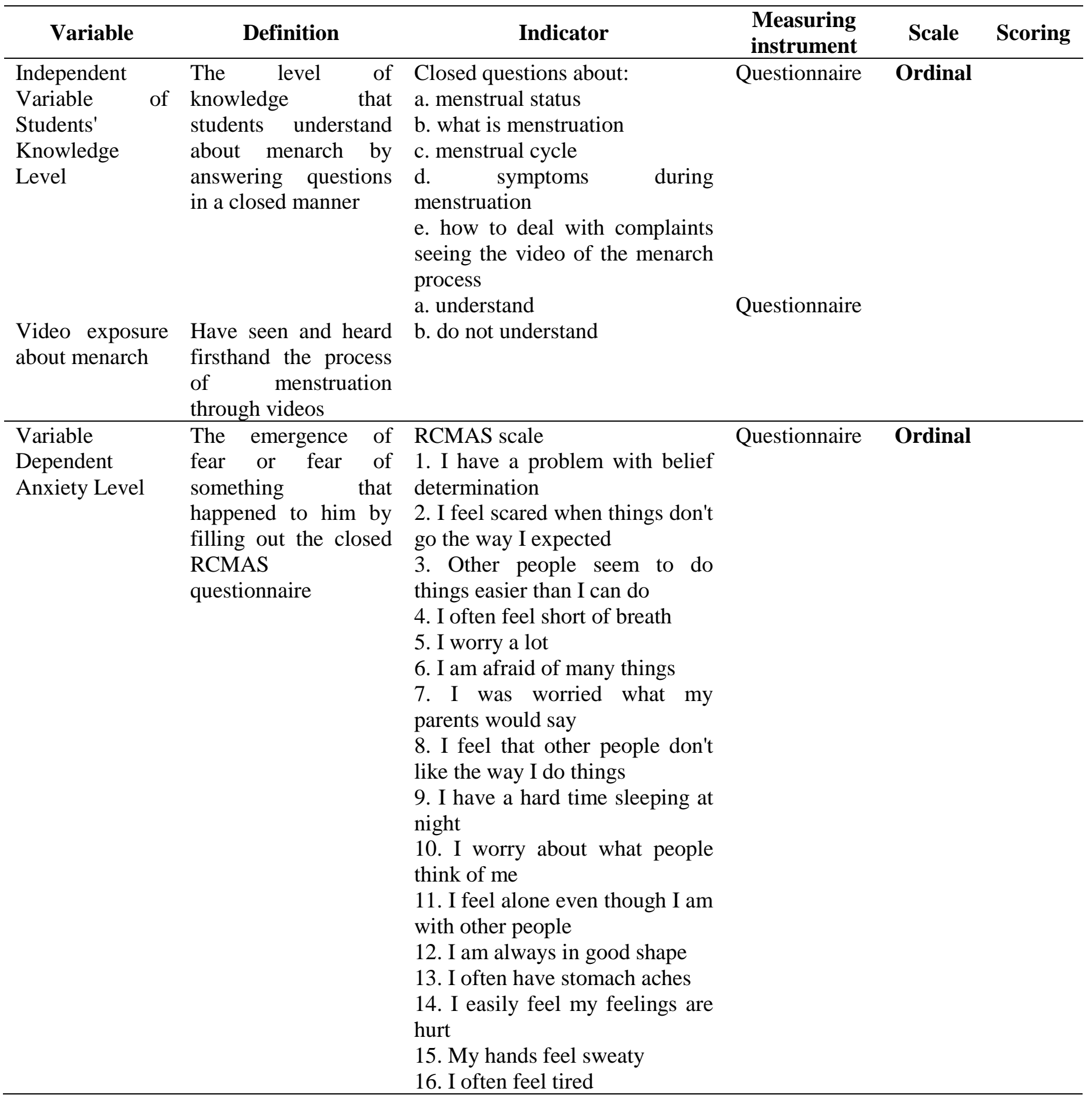




\section{Data analysis}

The processed data is then analyzed as a consideration for decision making (Setiadi, 2007), After the data was collected from the results of observations before and after the treatment was obtained, data processing was carried out to calculate the effectiveness of the treatment. To determine the effect of health education on menstruation on the anxiety of grade 5 and 6 elementary school students in dealing with menarche at Gemarang 02 Elemntary School, Gemarang sub-district, Madiun Regency used a logistic regression test. with a significant level $(\alpha)=0.05$.

a. If $\mathrm{p}$ Value $\leq \alpha=0.05$ then there is an effect of health education on menstruation on the anxiety of grade 4 to 6 elementary school students in dealing with menarche at Elementary School 02 and Primary Islamic School Gemarang, Gemarang district, Madiun Regency.

b. If $p$ Value $>\alpha=0.05$ then there is no effect of health education on menstruation on anxiety of grade 4 to 6 elementary school students.

\section{RESEARCH RESULT}

The results of the research are presented in the form of tables, pictures and narratives that describe the purpose of the research to find out analysis of anxiety levels based on the level of knowledge and exposure to videos about menarch in Elementary School 02 and Islamic Primary School 01 students in Gemarang, Madiun district.

1. Characteristics of Respondents

Table 2. Characteristics of Respondents by Age at Elementary School 02

\begin{tabular}{crc}
\hline Age & Amount & Percentage\% \\
\hline 10 years & 3 & 5,4 \\
11 years old & 7 & 12.5 \\
12 years old & 24 & 43 \\
13 years old & 22 & 39.1 \\
Total & 56 & 100 \\
\hline
\end{tabular}


Based on table 2. of the 56 respondents who have 10 years of age there are 3 respondents (5.4\%), 7 respondents aged 11 years $(12.5 \%), 24$ years of age 12 years $(43 \%)$ and 13 years of age there are 22 respondents $(39.1 \%)$. The most respondents were 12 years old.

Table 3. Characteristics of Respondents by Age at Islamic Primary School 01

\begin{tabular}{ccc}
\hline Age & amount & Percentage\% \\
\hline 10 years & 5 & 7,1 \\
11 years old & \multicolumn{1}{c}{11} & 19.4 \\
12 years old & 24 & 43 \\
13 years old & 16 & 28.6 \\
Total & 56 & 100 \\
\hline
\end{tabular}

Based on table 3. of the 56 respondents who have 10 years of age there are 5 respondents (7.1\%), 11 years of age there are 11 respondents (19.4\%), 12 years of age there are 24 respondents $(43 \%)$ and 13 years of age there are 16 respondents $(28.6 \%)$. The most respondents were 12 years old.

Table 4. Characteristics of Respondents by Age of First Time Menarch at Elementary School 02

\begin{tabular}{ccc}
\hline Age & amount & Percentage $\%$ \\
\hline 10 years & 0 & 0 \\
11 years old & & 7 \\
12 years old & 28 & 51.8 \\
13 years old & 18 & 33.2 \\
Total & 53 & 100
\end{tabular}

Based on table 4. of the 56 respondents who experienced menarch at the age of 10 years there were 0 respondents $(0 \%)$, who experienced menarch at the age of 11 years there were 7 respondents (13\%), who experienced menarch at the age of 12 years there were 28 respondents $(51.8 \%)$ and those who experienced menarch at the age of 13 were 18 respondents $(32.1 \%)$. Respondents who experienced the most menarchs were 12 years old.

Table 5. Characteristics of Respondents by Age of First Time Menarch at Islamic Primary School 01

\begin{tabular}{ccc}
\hline Age & amount & Percentage\% \\
\hline 10 years & 1 & 17.8 \\
11 years old & 9 & 16.1 \\
12 years old & 26 & 46.4 \\
13 years old & 20 & 35.7 \\
Total & 56 & 100 \\
\hline
\end{tabular}

Based on table 5. of the 56 respondents who experienced menarch at the age of 10 years there was 1 respondent $(17.8 \%)$, who experienced menarch at the age of 11 years there were 9 respondents $(16.1 \%)$, who experienced menarch at the age of 12 years there were 26 respondents ( $46.4 \%$ ) and those who experienced menarching at the age of 13 were 20 respondents $(35.7 \%)$. Respondents who experienced the most menarchs were 12 years old. 
2. The anxiety level of Elementary School 02 students in Gemarang District, Madiun Regency

Based on the results of research conducted on 56 respondents as an experimental group. Here are the results of student anxiety levels as follows:

Table 6. Anxiety Levels of Elementary School Students 02

\begin{tabular}{cccccc}
\hline Anxiety & \multicolumn{2}{c}{ Pretest } & \multicolumn{2}{c}{ Posttest } & \multirow{2}{*}{ F } \\
\cline { 2 - 5 } Level & $\mathrm{F}$ & $\%$ & $\mathrm{~F}$ & $\%$ & \\
\hline Anxious & 50 & 89.3 & 10 & 17.9 & 50 \\
Don't worry & 6 & 10.7 & 46 & 82.1 & 6 \\
\hline Total & 56 & 100 & 56 & 100 & 56 \\
\hline
\end{tabular}

In Table 6. it can be interpreted that on average $89.3 \%$ of students experienced anxiety before carrying out health education about menarce through video media, then after education as many as $82.1 \%$ of students did not experience anxiety about menarche.

3. The level of anxiety among Islamic Primary School 01 students in Gemarang District, Madiun Regency

Based on the results of research conducted on 56 respondents as a control group. Here are the results of student anxiety levels as follows:

Table 7. The level of anxiety of Islamic Primary School 01 students

\begin{tabular}{cccccc}
\hline Anxiety & \multicolumn{2}{c}{ Pretest } & \multicolumn{2}{c}{ Posttest } & \multirow{2}{*}{ F } \\
\cline { 2 - 5 } Level & F & $\%$ & F & $\%$ & \\
\hline Anxious & 51 & 91.1 & 34 & 60.7 & 43 \\
Don't worry & 5 & 8.9 & 22 & 39.3 & 13 \\
\hline Total & 56 & 100 & 56 & 100 & 56 \\
\hline
\end{tabular}

In Table 7, it can be interpreted that on average, $91.1 \%$ of students experienced anxiety before carrying out health education about menarce through video media, then after education, $39.3 \%$ of students did not experience anxiety about menarche.

4. The level of knowledge in Elementary School 02 students in Gemarang District, Madiun Regency

Based on the results of research conducted on 56 respondents as an experimental group. Here are the results of the student's knowledge value as follows:

Table 8. The level of knowledge of Elementary School 02 students

\begin{tabular}{cccccc}
\hline \multirow{2}{*}{ Knowledge } & \multicolumn{2}{c}{ Pretest } & \multicolumn{2}{c}{ Posttest } & \multirow{2}{*}{ F } \\
\cline { 2 - 5 } & F & $\%$ & F & $\%$ & \\
\hline Not good & 50 & 89.3 & 10 & 17.9 & 30 \\
Good & 6 & 10.7 & 46 & 82.1 & 26 \\
\hline Total & 56 & 100 & 56 & 100 & 56 \\
\hline
\end{tabular}

In Table 8. it can be interpreted that the average knowledge of students about menarch before being given health education is not good as much as $89.3 \%$. Then after carrying out health education, it was $82.1 \%$ good.

5. Identifying the level of knowledge among Islamic Primary School 01 students in Gemarang District, Madiun Regency

Based on the results of research conducted on 56 respondents as a control group. Here are the results of the student's knowledge value as follows:

Table 9. Knowledge level of Islamic Primary School 01 students

\begin{tabular}{cccccc}
\hline \multirow{2}{*}{ Knowledge } & \multicolumn{2}{c}{ Pretest } & \multicolumn{2}{c}{ Posttest } & \multirow{2}{*}{ F } \\
\cline { 2 - 5 } & f & $\%$ & F & $\%$ & \\
\hline Not good & 49 & 87.5 & 38 & 67.9 & 44 \\
Good & 7 & 12.5 & 18 & 32.1 & 12 \\
\hline Total & 56 & 100 & 56 & 100 & 56 \\
\hline
\end{tabular}


In Table 9. it can be interpreted that the average knowledge of students about menarch before being given poor health education is $87.5 \%$. Then after doing the posttest without treatment, the knowledge was not good enough as much as $67.9 \%$.

\section{Bivariate Analysis}

1. Knowing the relationship between Elementary School 02 students' knowledge and anxiety levels.

Based on the results of research conducted on 56 respondents as an experimental group. Here is the relationship between knowledge and student anxiety levels as follows:

Table 10. the relationship between knowledge and anxiety levels

\begin{tabular}{cccccc}
\hline \multirow{3}{*}{ Knowledge } & \multicolumn{4}{c}{ Anxiety Level } & \multirow{2}{*}{ Sig } \\
\cline { 2 - 5 } & \multicolumn{2}{c}{ Anxious } & \multicolumn{2}{c}{ Don't worry } & \\
\cline { 2 - 5 } & $\mathrm{f}$ & $\%$ & $\mathrm{f}$ & $\%$ & \\
\hline Not good & 2 & 3,6 & 8 & 14.3 & \multirow{2}{*}{$0.001 *$} \\
Good & 8 & 14.3 & 38 & 67.9 & \\
\hline Total & 10 & 17.9 & 46 & 82.1 & \\
\hline
\end{tabular}

In Table 10, it can be interpreted that there is a relationship between student knowledge after being given educational education using video media with a level of anxiety with a significant value of $0.001<0.05$.

2. The relationship between Islamic Primary School 01 students' knowledge and anxiety levels Based on the results of research conducted on 56 respondents as a control group. Here is the relationship between knowledge and student anxiety levels as follows:

Table 11. the relationship between knowledge and anxiety levels

\begin{tabular}{|c|c|c|c|c|c|}
\hline \multirow{3}{*}{ Knowledge } & \multicolumn{4}{|c|}{ Anxiety Level } & \multirow[t]{3}{*}{ Sig } \\
\hline & \multicolumn{2}{|c|}{ Anxious } & \multicolumn{2}{|c|}{ Don't worry } & \\
\hline & $\mathrm{F}$ & $\%$ & $\mathrm{f}$ & $\%$ & \\
\hline Not good & 18 & 32.1 & 20 & 35.8 & $0.006 *$ \\
\hline Good & 15 & 26.9 & 3 & 5,4 & \\
\hline Total & 33 & 15.9 & 23 & 82.1 & \\
\hline
\end{tabular}

In Table 11, it can be interpreted that there is a relationship between student knowledge after being given educational education using video media with a level of anxiety with a significant value of $0.006<0.05$.

3. The relationship between health education using video media on the level of anxiety

Based on the results of research conducted on 56 respondents as the experimental group and 56 respondents as the control group. The following shows the relationship between health education using video media and student anxiety levels as follows:

Table 12. The relationship between health education using video and the level of anxiety

\begin{tabular}{|c|c|c|c|c|c|}
\hline \multirow{3}{*}{ Treatment } & \multicolumn{4}{|c|}{ Anxiety Level } & \multirow[t]{3}{*}{ Sig } \\
\hline & \multicolumn{2}{|c|}{ Anxious } & \multicolumn{2}{|c|}{ Don't worry } & \\
\hline & $f$ & $\%$ & $f$ & $\%$ & \\
\hline Using video & 5 & 8.9 & 23 & 41.1 & $0,000 *$ \\
\hline $\begin{array}{l}\text { Without } \\
\text { treatment }\end{array}$ & 17 & 30.4 & 11 & 19.6 & \\
\hline Total & 10 & 17.9 & 46 & 82.1 & \\
\hline
\end{tabular}

In Table 12. it can be interpreted that there is a relationship between the provision of health education using video and the level of anxiety with a significant value of $0.000<0.05$. 


\section{Multivariate Analysis}

1. The level of anxiety based on the level of knowledge and exposure to videos about menarch in Elementary School 02 and Islamic Primary School 01 students in Gemarang, Madiun district

Based on the results of research conducted on 56 respondents as the experimental group and 56 respondents as the control group. The following shows the influence of health education using video media based on the level of knowledge on student anxiety levels using logistic regression analysis as follows:

Table 13. The effect of health education using video based on the level of knowledge on anxiety

\begin{tabular}{cccc}
\hline & B & Sig & Exp (B) \\
\hline Health education & $-2,756$ & $0,000 *$ & 0,064 \\
Knowledge & $-1,354$ & $0.028 *$ & 0.258 \\
\hline Constant & 6,826 & 0.006 & $1.087 \mathrm{E} 3$
\end{tabular}

*) Logistic Regression is Significant at $<0.05$

Based on the table above, the significant value in health education is $0.000<0.05$, so that there is an effect of health education using video on student anxiety levels with an influence coefficient value of 2.756. Meanwhile, for knowledge with a significant value of $0.028<0.05$, there is an effect of knowledge with the level of anxiety with an influence coefficient value of 1.354 . The logistic regression equation model is as follows:

$$
\begin{gathered}
\text { logit }=\beta a+\beta 1 X 1+\beta 2 X 2+c \\
\text { logit }=6,991+2,812 X 1+1,441 X 2+c
\end{gathered}
$$

From the exp value (B1), it can be seen that the provision of health education using video has an opportunity for students to feel less anxious 0.560 times more than respondents who did not receive health education using video. The exp value (B2) of 0.244 means that an increase in knowledge of 1 will result in a change of 0.028 in the level of anxiety. Thus, if there is an increase in students' knowledge from low to high, it will reduce the probability of anxiety levels by 0.244 . To prove the correctness of the model, it can be seen in the following provisions:

Table 14. Logistic regression test criteria

\begin{tabular}{lll}
\hline R Square & Chi-Square & Sig \\
\hline 2.97 & 4,429 & 0,109 \\
\hline
\end{tabular}

Based on the table above, the Nagelkerke R Square value is 2.97 or $29.7 \%$. Thus it can be interpreted that with 2 variables, namely health education using video and the level of student knowledge, the level of anxiety can be explained by $29.7 \%$. Then from the chi-square test value, it is obtained a significant value of 4.429>0.05, it means that the model is sufficient to explain the data (goodness of fit).

\section{DISCUSSION}

Based on the results of research that has been done, the relationship between health education using videos about menarch and anxiety levels was obtained $p=0.001<0.05$. The level of anxiety in students in facing menarche after being given audio video method health education on Elementary School 02 and Islamic Primary School 01 students in grade 4, grade 5 and grade 6 in Gemarang, Madiun Regency.This is in line with Eka's research (2019), which states thatThere is an effect of health education with video media on Elementary School (SD) side anxiety in dealing with 
menarchewith the average value of the level of anxiety before being given health education is 24.00 and anxiety after being given health education to 14.00 .

According to Rohani (in Harmawan 2007) audio-visual media is a modern interactional media that is in accordance with the times (advances in science and technology) including media that can be seen and heard. Apart from entertainment media, the language is clear in language that is easily understood by all groups and ages.This is in line with the theory expressed by Prastowo, A (2012),the benefits of video media as educational media: providing unexpected experiences to students, showing real things that at first could not be seen, analyzing changes in a certain time period, providing experiences to students [to feel a certain situation, and displaying presentations real-life case studies that can spark student discussions. This shows that exposure to video can affect a person's learning process.

Table 4.1 shows that the percentage of respondents who experienced anxiety before being given health education using video media was $89,3 \%$. Then after education using video media students experienced anxiety to $17.9 \%$ and $82.1 \%$ of students did not experience anxiety. So the results show thathealth education using video media can reduce anxiety levels amounted to $82.1 \%$. Anxiety is a mood disorder that is usually unpleasant which is a manifestation of the central nervous system alarm system that occurs due to the fight or flight reaction which triggers the release of adrenaline and other catecholamines so that the heart rate and respiratory rate increase and palpitations (Puri, et al. ., 2011). In addition, anxiety also affects the cognitive aspects of a person, if a person's anxiety increases, there will be a decrease in the ability to think clearly and cause concentration problems (Isnaini \& Lestari, 2015; Apriady, et al., 2016).

Anxiety is one of the causes of decreased student achievement because when a student experiences an increase in anxiety there will be a feeling of discomfort which will interfere with the student's concentration in learning. In addition, physically the result of an increase in anxiety is health problems such as indigestion and sleep disorders that can interfere with the student's learning process and even reduce the student's learning time. With the disruption of the student learning process, the learning outcomes obtained by these students are not optimal and have an impact on the low student achievement. This is in line with previous research conducted by Lepp et al. (2014) that anxiety has a negative relationship with academic achievement or student achievement (Lepp, et al., 2014). This shows that an increase in anxiety will lead to disruption in the learning process which can be seen from the decrease in individual learning outcomes.

The results of the analysis of the relationship between anxiety levels and student achievement of Senior High School 1 Semin obtained a value of $r=-0.357$ which indicates that there is a weak correlation. So in accordance with the research of Demak and Suherman (2016) that increased anxiety is related to learning achievement based on their research, one of the results of increased anxiety is a decrease in learning achievement.

\section{The Relationship of Health Education Using videos and knowledge on anxiety levels}

Based on multivariate analysis using logistic regression, it shows the p-value 0.002 so that it can be interpreted that there is an effect of health education using video on students' knowledge and anxiety levels. Health education using video media will increase students' knowledge. It is seen that there is a relationship between health education and knowledge with $\mathrm{p}$ value 0.005 .

Knowledge is the result of knowing and this occurs after people sensing a certain object. Knowledge basically consists of a number of facts and theories that enable a person to be able to solve the problems they face. This knowledge is obtained both from direct experience and through the experiences of others. The factors that influence knowledge include: age, experience, education, occupation, gender, information, environment, socio-culture. Students who have sufficient knowledge, but are not ready to face Menarche this is due to factors from the local environment which consider menstruation to be taboo

Health education using video media can increase students' knowledge. Through video media, a person is able to absorb the material presented optimally, because the message is conveyed audio and visually. With an increase in students' knowledge about menarchs, it is hoped that the attitude in 
dealing with menarchs will be better. Thus, along with the increase in students' knowledge, the level of anxiety will decrease.

Based on the results of research that had been carried out with a good level of knowledge, $82.1 \%$ of students felt that they were not anxious. The results of this study are consistent with research conducted by Shilfia in 2017 which shows that most of the students' level of knowledge at Elementary School 1 Jetis has a sufficient category, namely 23 people (58\%). In Maria's 2012 study also showed that the highest level of knowledge of students about menarche in the moderate category, namely 34 students (54\%).

According to Rohani (in Harmawan 2007) audio-visual media is a modern interactional media that is in accordance with the times (advances in science and technology) including media that can be seen and heard. Apart from entertainment media, the language is clear in language that is easy to understand for all groups and ages. This is in line with the theory expressed by Prastowo, A (2012), the benefits of video media as an educational medium: providing unexpected experiences to students, showing real things that were initially impossible to see, analyzing changes in a certain time period, providing experiences for students to feel a certain situation, and presenting study presentations reallife cases that can spark learners' discussions. This shows that exposure to video can affect a person's learning process.

Knowledge about menstruation is conveyed in depth and uses interesting media, namely visual audiences so that it is easier to understand. Through increased knowledge, students will know more about the physiology of menstruation so that they will be better psychologically prepared to face menstruation. The readiness of young women in dealing with menstruation will certainly affect the level of stress and also the level of anxiety they face.

A person with a good level of knowledge will have better psychological readiness in dealing with menstruation. Psychological readiness needs to be prepared with education or health education from an early age. Therefore, it is very emphasized for health workers, especially midwives to assist in providing health education to elementary school students related to reproductive health.

Proper health education is used based on the results of research that has been done, namely by using media that is in accordance with technological developments. The development of educational media that is currently being enjoyed by the public is using video media. Through video media, the researchers did in reducing the anxiety level of students in dealing with menstruation successfully through increased knowledge. Thus, health workers can play a role in increasing students' knowledge which aims to reduce anxiety levels during menstruation. A decrease in the level of anxiety will be able to increase the productivity of students who are menstruating so that the learning process can be carried out optimally and students can work better.

\section{CONCLUSIONS}

Based on the results of the statistical analysis carried out, it can be concluded that:

a. There is an effect on the level of anxiety based on the level of knowledge and exposure to videos about menarch on Elementary School 02 and Islamic Primary School 01 students in Gemarang, Madiun district with a $\mathrm{p}$ value of 0.002

b. The level of anxiety in Elementary School 02 students before being given health education using video was $89.3 \%$ then after being given health education using video, it decreased the respondent's anxiety level by $71.4 \%$ so that students who still experienced anxiety after being given health education used video by $17.9 \%$.

c. The level of anxiety in Islamic Primary School 01 students before being given health education using video was $91.9 \%$ then after the post test without intervention, the respondent's anxiety level was $31.2 \%$ so that students who still experienced anxiety during the post test were $60.7 \%$.

d. The level of knowledge was not good for Elementary School 02 students before being given health education using video was $89.3 \%$, then after being given health education using video, there was an increase in student knowledge by $71.4 \%$ so that students who still had poor knowledge after being given health education used video magnitude $17.9 \%$.

e. The level of poor knowledge of Islamic Primary School 01 students before being given health education using video was $87.5 \%$ then after being given health education using video, the increase 
in student knowledge was $55.4 \%$ so that students who still had poor knowledge after being given health education used video magnitude $32.1 \%$.

f. There is a relationship between Elementary School 02 students' knowledge and anxiety level with a p-value of 0.005

g. There is a relationship between the knowledge of Islamic Primary School 01 students and the level of anxiety with a $\mathrm{p}$ value of 0.026

h. There is a relationship between the provision of health education using video to the level of anxiety with a p-value of 0.001 .

\section{REFERENCES}

Ciptorini., 2017. The Importance of Adolescent Reproductive Health Information, accessed on April 10, 2011 from http: //kespro\%dinkes.html.

Dariyo, 2014.Psychology of Adolescent Development, Bogor: Ghalia Indonesia.

Djamarah, 2015. Adolescent Reproductive Health Education, Yogyakarta: Graha Ilmu.

Dorland, 2015. Medical Pocket Book. Jakarta: EGC

Ferry, 2010. Coping for Menarche Adaptation as a Strategy to Improve Adolescent Reproductive Health.

Availableconline: http://ferryefendi.blogspot.com/2007/11/koping-adaptasimenarchesebagai.html, 20 March 2018.

Fitriani S, 2014. Health Promotion. Yogyakarta: Graha Science.

Hidayat, 2012. Midwifery Methodology and Data Analysis Techniques. Jakarta: Salemba Medika. http:www.arsip-indoscript.co.cc/2010/06/-others research results.html.accessed on March 26, 2018.

Hurlock, EB, 2004. Developmental Psychology of an Approach Throughout the Span of Life Edition 5, Prints 11. Jakarta: Erlangga.

Jones, D., 2012, Basics of Obstetrics and Gynecology, interpreted by dr. Hadiyanto, Hipokrates, Jakarta.

Kartono, K., 2016. Psychology of Women 1 Knowing Adolescent Girls and Adult Women. Bandung: Mandar Maju.

Manuaba, IBG 2012. Understanding Women's Reproductive Health. Jakarta: Arean.

Notoatmodjo, S., 2013. Health Research Methodology. Jakarta: Rineka Cipta.

Nurmazika F, 2014. An illustration of young women unpreparedness in facing menarche in Petarukan sub-district. Ungaran: NWU.

Nursalam, 2016. Concept and Application of Nursing Research Methodology: Thesis Guidelines, Thesis and Nursing Research Instruments. Jakarta: Salemba Medika.

Prawirohardjo, S., 2013. National Reference Book for Maternal and Neonatal Health Services. Jakarta: Bina Pustaka Foundation.

Proverawati A, Siti M., 2012. The First Menarche is Meaningful. Yogyakarta: Muha Medika.

Riyanto A, 2011. Application of Health Research Methodology, Yogyakarta: Muha Medikak.

Ratih, 2010 Anxiety disorders in anaksalemba medika

Saryono, A., 2008, Midwifery Research Methods DIII, DIV, S1 and S2. Yogyakarta: Muha Medika.

Sugiyono, 2011. Statistics for Research. Bandung: Alfabeta.

Wiji, 2008, "The Relationship between Knowledge Level of Menstruation and Readiness of Grade V and Grade VI Students to Face Menarche at SD Budi Mulia Dua Seturan, Sleman. Yogyakarta: Respati.

Purnamasari S, 2010. "The Relationship between Reproductive Health Knowledge and Readiness to Face the Changes of Puberty in Grade V and VI of SD Negeri 01 Candirejo Ungaran". Ungaran: NWU.

Wiknjosastro, H., 2012. Obstetrics. Jakarta: Bina Pustaka Sarwono Prawirohardjo Foundation.

Wong., 2015 Efforts to Prevent Anxious Children

Yetty, Asmar., 2015, Psychology of Mother and Child. Yogyakarta: Fitramaya. 